УДК 344.7

DOI https://doi.org/10.32849/2663-5313/2021.6.18

\title{
Наталія Борисочева,
}

аспірант кафедри адміністративного, иивільного та господарського права і прочесу

Академї Державної пенітенціарної служби України

\section{ТЕОРЕТИЧНІ ПІДХОДИ ДО РОЗУМІННЯ СИСТЕМИ ОРГАНІВ ВИКОНАВЧОЇ ВЛАДИ}

У иій науковій статті на підставі аналізу теоретичних підходів науковців-адміністративістів щодо теорії органів виконавчої влади та їх системи досліджено теоретичні підходи до розуміння системи органів виконавчої влади, що дало змогу автору запропонувати власне визначення органу виконавчої влади та дослідити проблемні питання його діяльності.

Визначено, що основними рисами органу виконавчої влади є: 1) є частиною публічної адміністрації; 2) являє собою організачію, тобто колектив людей, об'єднаних для вчинення спільних дій; 3) створюється з волі держави та реалізує ӥ; 4) має політичні та державні посади; 5) його діяльність спрямована на вчинення державно-виконавчих дій, є підзаконною; 6) здійснює діяльність в межах компетениї, тобто на підставах, у порядку і у спосіб, передбачені законодавством; 7) має атрибути юридичної особи (відокремлене майно, рахунок, печатку, итамп тощо).

Підкреслено, що органи виконавчої влади - ие частина державного апарату, що має власну структуру та штат службовців і в межах установленої компетениї здійснює на основі законів та на їх виконання, від свого імені й за дорученням народу України підзаконне адміністративно-правове регулювання (адміністрування) в галузях, сферах і секторах суспільних відносин.

Система органів виконавчої влади являє собою сукупність, в якій усі складові частини (окремі органи та їх структурні підрозділи) є взаємопов'язаними і водночас становлять самостійні підсистеми зі своїми особливостями структури, функиій, компетениї. Побудова иієї системи грунтується на засадах єдності та иілісності державної території, поєднання принципів централізації та децентралізачї, збалансованості сочіально-економічного розвитку регіонів залежно від адміністративнотериторіального устрою країни.

Визначено, що державні комісій - ие иентральний колегіальний орган виконавчої влади, діяльність якого спрямовує та координує Кабінет Міністрів Украйни через окремо визначеного Міністра; проиедура призначення ї членів та керівника, припинення ї повноважень визначена спечіальним законом України, основним призначенням якої є виконання окремих функиій з реалізації державної політики.

Ключові слова: орган виконавчої влади, колегіальний орган, державно-владні повноваження, державний апарат, Кабінет Міністрів, міністерство, державна комісія.

Постановка проблеми. Нині система центральних органів виконавчої влади побудована таким чином, що функції щодо здійснення контролю і нагляду, надання послуг та управління об’єктами державної власності здійснюють відповідно державні інспекції, державні служби та агентства. Втім, нещодавно Законом України «Про внесення змін до Закону України «Про центральні органи виконавчої влади» були створені державні комісії. Саме тому доцільно розібратися з повноваженнями даних органів.

Мета статті - визначити основні риси органів виконавчої влади, висвітлити підходи до їх класифікації, розкрити систему органів виконавчої влади.

Аналіз останніх досліджень. Окремі питання діяльності центральних органів виконавчої влади були предметом досліджень В.Б. Авер'янова, С.Г. Сте- ценко, В.К. Колпакова, О.В. Кузьменко, Ю.П. Битяка, В.М. Гаращука, В.В. Зуй, Н.Р. Нижник та ін.

Виклад основного матеріалу. У систему публічної адміністрації входять органи виконавчої влади, які наділені відповідними державно-владними повноваженнями в усіх сферах суспільного і державного життя. Особливість виконавчої влади серед гілок державної влади, на думку В.Б. Авер'янова, полягає в тому, що саме у процесі їі реалізації відбувається реальне втілення в життя законів та інших нормативних актів держави, практичне застосування важелів державного регулювання й управління важливими процесами суспільного розвитку [1, с. 15].

Підтримуючи загалом вищевикладену позицію, С.Г. Стеценко зазначає, що виконавча влада $є$ найбільшою за людським (чисельним), матеріальним та фінансовоекономічним потенціалом гілкою влади, яка 
займається деталізацією законів шляхом виконавчо-розпорядчої діяльності та прийняття підзаконних документів. Виконавча влада в Україні призначена здійснювати контрольні повноваження, управління державним майном, антимонопольну діяльність та багато іншого. Суто ж виконання законів не є домінуючим серед інших складників призначення виконавчої влади [2, с. 69].

Професори В.К. Колпаков та О.В. Кузьменко формулюють поняття «орган виконавчої влади» як носія державної виконавчої влади, що реалізує свою компетенцію в закріпленій сфері державного управління і має юридичний (нормативно зафіксований) статус органу виконавчої влади [3, с. 91].

Н.П. Матюхіна під органом виконавчої влади розуміє частину державного апарату (організацію), яка має власну структуру та штат службовців, територіальний масштаб діяльності, утворюється в установленому законом або іншими правовими актами порядку і в межах передбаченої компетенції здійснює від імені і за дорученням держави функції державного управління в економічній, соціально-культурній, адміністративно-політичній сферах суспільного життя [4, с. 75-76].

Колектив авторів, який очолювала Н.Р. Ніжник, зазначив, що виконавча влада відрізняється від інших видів влади своїми специфічними методами, що використовуються для досягнення своїх цілей. Ї̈̈ характеризує поєднання таких основних елементів механізму проведення в життя владної волі, як примус, маніпулювання, переконання, авторитет і традиція тощо. Сутнісною ознакою виконавчої влади вони виділили примусовість, покладання на силу, можливість самостійно здійснювати фізичні, організаційні та інші заходи примусу [5, с. 31].

Українське законодавство поняття «органи виконавчої влади» визначає як самостійний вид органів державної влади, які, згідно $з$ конституційним принципом поділу державної влади, мають своїм головним призначенням здійснення однієї гілки державної влади - виконавчої [6]

Беручи до уваги зазначені вище погляди науковців, Н.П. Тиндик виокремлює чотири головні підходи щодо визначення поняття виконавчої влади: як вольових відносин; як орану держави; як функції; як сукупності повноважень. Науковець зауважує, що, на жаль, не кожен науковий термін, поняття можуть бути формалізовані, тобто закріплені в нормах закону. Наприклад, відомо, що суспільні відносини виконавчої влади відрізняються декількома головними особливостями, що є підставою для їхнього від- окремлення від інших гілок влади. Головною особливістю об'єкта цих відносин є те, що для суб'єкта адміністративно-правових відносин особливістю буде наявність обов'язкового суб'єкта - органу (посадової особи) виконавчої влади. Головною особливістю змісту адміністративних правовідносин $є$ наявність владних повноважень. Тлумачення виконавчої влади як владних відносин навряд чи зможе бути вираженим мовою права. Продуктивне в загальнотеоретичному аспекті прагнення закріпити виконавчу владу як функцію має цілий ряд невирішених проблем техніко-юридичного плану, але це не означає повної неспроможності зафіксувати юридичними нормами соціальні та правові складники виконавчої влади [7, с. 108; 8, с. 109]. 3 даними роздумами ми не можемо погодитися, оскільки найчіткіше визначення поняття «орган виконавчої влади» призвете до чіткого визначення його правового статусу, компетентності, обсягу повноважень тощо. Саме тому законодавець повинен прагнути до повноти обсягу того чи іншого визначення. Певний час відбувалась дискусія щодо визнання за органами виконавчої влади в Україні правового статусу «органів державної влади» чи «органів державного управління», але сьогодні політична спрямованість компетенції Кабінету Міністрів України i, дещо меншою мірою, центральних та місцевих органів виконавчої влади звела цю дискусію нанівець, оскільки сучасні тенденції щодо розуміння сутності органів виконавчої влади саме зводяться до реалізації політичного курсу коаліційної більшості Верховної Ради України, яка обирає шляхом голосування членів Кабінету Міністрів України. Відповідно, введено поняття «політична посада», під якою можливо розуміти один із видів посад публічної служби, що своїми особливостями i політико-правовими засадами суттєво відрізняється від інших посад публічної служби, зокрема державної служби. Політичний характер зазначеного виду посад не обмежується лише фактом обов'язкової приналежності особи, яка займає цю посаду, до певної політичної партії, хоча саме така ситуація є нормою у державотворчій практиці багатьох демократичних країн світу. Там саме політичні посади заміщуються представниками партії, яка перемогла на виборах. Тобто партії висувають свої кадри на вищі державні посади. I це логічно, адже політика певної партії (чи коаліції партій), яка отримала найбільшу підтримку населення на виборах, стає державною політикою. При цьому практика діяльності вищих посадових осіб вимагає поєднання принципу партійності з принци- 
пом професійності в період здійснення правлячою партією державно-владних повноважень [9, с. 72].

Відповідно, основними рисами органу виконавчої влади є: 1) є частиною публічної адміністрації; 2) являє собою організацію, тобто колектив людей, об'єднаних для вчинення спільних дій; 3) створюється 3 волі держави та реалізує іï; 4) має політичні та державні посади; 5) його діяльність спрямована на вчинення державно-виконавчих дій, є підзаконною; 6) здійснює діяльність в межах компетенції, тобто на підставах, у порядку і у спосіб, передбачені законодавством; 7) має атрибути юридичної особи (відокремлене майно, рахунок, печатку, штамп тощо).

Отже, органи виконавчої влади - це частина державного апарату, що має власну структуру та штат службовиів $і$ в межах установленої компетениії здійснює на основі законів та на їх виконання, від свого імені й за дорученням народу Украйни підзаконне адміністративно-правове регулювання (адміністрування) в галузях, сферах і секторах суспільних відносин [10].

Система органів виконавчої влади являе собою сукупність, в якій усі складові частини (окремі органи та їх структурні підрозділи) є взаємопов'язаними і водночас становлять самостійні підсистеми зі своїми особливостями структури, функцій, компетенції. Побудова цієї системи грунтується на засадах єдності та цілісності державно території, поєднання принципів централізації та децентралізації, збалансованості соціально-економічного розвитку регіонів залежно від адміністративно-територіального устрою країни. Система органів виконавчої влади утворюється 3 урахуванням забезпечення державного суверенітету й економічної самостійності України, проведення фінансової, цінової, інвестиційної та податкової політики, політики у сферах праці і зайнятості населення, соціального захисту, освіти, науки, культури, охорони природи, екологічної безпеки природокористування, а також здійснення загальнодержавних програм економічного, науково-технічного, соціального та культурного розвитку України. Побудова та удосконалення системи і підсистем органів виконавчої влади відбуваються з урахуванням необхідності єдиного центру керівництва економічними та соціальними справами на основі планування, ринкових відносин, рівності усіх форм власності, поєднання галузевого і територіального принципів управління, їх централізації з відповідною самостійністю регіонів та окремих адміністративно-територіальних одиниць, господарською самостійністю підприємств, об'єднань та інших суб'єктів [11]

У системі органів виконавчої влади виокремлюються три організаційно-правові структурні ланки, а саме:

1) вища - Кабінет Міністрів України; 2) центральна - міністерства, державні служби, державні агентства, державні інспекції, комісії [12] та центральні органи виконавчої влади зі спеціальним статусом; 3) адміністративно-територіальна - територіальні органи виконавчої влади та місцеві державні адміністрації.

За формою діяльності органи виконавчої влади в Україні є переважно єдиноначальними (міністерство, інший ЦОВВ, місцева державна адміністрація). Вони очолюються керівником, який самостійно організовує їхню роботу та несе відповідальність за неї. Разом із тим Кабінет Міністрів України $€$ вищим колегіальним органом виконавчої влади. До того ж у кожному міністерстві та ЦОВВ діють колегії. Це дозволяє говорити про поєднання колегіальності та єдиноначальності в організації та діяльності органів виконавчої влади в Україні.

За походженням - первинні (Кабінет Міністрів України) та похідні (центральні органи виконавчої влади і місцеві державні адміністрації); за змістом (предметом) діяльності - міністерства, служби, агентства, інспекції; за порядком організації та діяльності - колегіальні (Кабінет Міністрів України, комісії та ін.) та єдиноначальні (міністерства, державні служби та ін.); за характером - загальної компетенції (Кабінет Міністрів України), галузевої (Міністерство охорони здоров'я та ін.), міжгалузевої (Міністерство фінансів України та ін.), спеціальної (Служба безпеки України та ін.); за часом дії - постійні (Кабінет Міністрів України та ін.), тимчасові (спеціально створені органи); за назвою - Кабінет, Рада, Міністерство, Державна служба тощо [13].

Також є науковий підхід класифікації органів виконавчої влади за функціональною спрямованістю керівників: а) органи з превалюванням політичних функцій (Кабінет Міністрів України, міністерства); б) органи 3 превалюванням виконавчих функцій (державні служби, інспекції, агентства, ЦОВВ зі спеціальним статусом) [14, с. 64].

Вищим органом у системі органів виконавчої влади в Україні є Кабінет Міністрів України, який очолюе систему органів виконавчої влади, є Урядом України, який здійснює виконавчу владу безпосередньо та через міністерства та інші центральні органи виконавчої влади, Раду Автономної Республіки Крим та місцеві державні адміні- 
страції, спрямовує, координує та контролює діяльність цих органів. Він відповідальний перед Президентом України і Верховною Радою України, підконтрольний і підзвітний Верховній Раді України у межах, передбачених Конституцією України (ст. 113 Конституції України).

Отже, Кабінет Міністрів України - це вищий орган у системі органів виконавчої влади, відповідальний перед Президентом України і Верховною Радою України, підконтрольний і підзвітний Верховній Раді України, що керується у своїй діяльності Конституцією, законами України, указами Президента України та постановами Верховної Ради України.

Основні повноваження Кабінету Міністрів України щодо адміністрування галузі авіації та використання повітряного простору України мають загальнодержавний та комплексний характер, який стосується:

здійснення заходів щодо забезпечення обороноздатності та національної безпеки України, громадського порядку, боротьби зі злочинністю, ліквідації наслідків надзвичайних ситуацій;

розроблення і виконання загальнодержавних програм науково-технічного розвитку, а також розроблення, затвердження і виконання інших державних цільових програм;

спрямування та координації роботи міністерств, інших органів виконавчої влади, здійснення контролю за їхньою діяльністю[15].

Центральною ланкою у системі органів виконавчої влади є підвідомчі Кабінету Міністрів України міністерства й інші центральні органи виконавчої влади. Особливість їхнього правового статусу полягає в тому, що саме міністерства й інші центральні органи виконавчої влади є головними управлінськими структурами у різних сегментах виконавчої влади.

Міністерства $є$ головними органами в системі центральних органів виконавчої влади у формуванні та забезпеченні реалізації державної політики в одній чи декількох сферах. Міністерства, що здійснюють управлінську діяльність в окремих галузях, називають галузевими. Ті, що здійснюють функціональну (міжгалузеву) управлінську діяльність у певних сферах, називають функціональними.

За Законом України «Про центральні органи виконавчої влади», окрім міністерств та центральних органів виконавчої влади зі спеціальним статусом, інші центральні органи виконавчої влади утворюються для виконання окремих функцій з реалізації державної політики, такі як служби, агентства, інспекції, комісії [12]. Основними завдан- нями центральних органів виконавчої влади $€: 1$. надання адміністративних послуг; 2. здійснення державного нагляду (контролю) 3. управління об'єктами державної власності; 4. внесення пропозицій щодо забезпечення формування державної політики на розгляд міністрів, які спрямовують та координують їхню діяльність. Центральні органи виконавчої влади можуть здійснювати одне або кілька визначених у переліку завдань [12]

Принагідно зауважимо, що нормативноправове розмежування відповідних інституцій не виключає наявність конвергенції функцій і дисонансу назв у системі «інших центральних органів виконавчої влади» (Державна податкова служба, Державна аудиторська служба та інші). Щодо вказаного проблемного аспекту дослідниками зазначається: «в ч. 2 ст. 17 Закону [12] для розмежування назв інших центральних органів виконавчої влади застосовано показник не виключності, а переважності («більшість функцій»). Варто наголосити, що головним при цьому все таки має залишатися сутнісний критерій, що є важливішим за формальний (кількісний)» [16, с. 31]. Таким чином, нечітке дотримання правила функціонального розмежування назв центральних органів виконавчої влади певною мірою має раціональне практичне обгрунтування, однак не виключає справедливості зауважень щодо цього [17, с. 283]. Дана проблема суттєво не впливає на призначення, межі компетенції даних центральних органів виконавчої влади, водночас недотримання норм закону $€$ елементом дисгармонії у системі цих органів, що ускладнює їх системне сприйняття.

Встановлений перелік «служби, агентства, інспекції» був нещодавно доповнений терміном «комісії». Законом не встановлено поняття «комісія» та не визначено його організаційної специфіки. У Юридичній енциклопедії наведене таке значення терміна «комісія»: уповноважена група осіб, обрана чи призначувана для виконання тимчасового або постійного доручення чи попередньої розробки будь-якого питання, а також виконання організаційних заходів (пр. виборча комісія, експертна комісія, тимчасова слідча комісія та інші) [5]. Відповідно, особливою ознакою цих органів $є$ колегіальність. Отже, державні комісії - ие центральний колегіальний орган виконавчої влади, діяльність якого спрямовує та координує Кабінет Міністрів України через окремо визначеного Міністра; прочедура призначення ї̈ членів та керівника, припинення ї̈ повноважень визначена спечіальним законом України, основним призначенням якої є виконання окремих функиій з реалізачї державної політики. 


\section{Висновки}

Отже, у результаті дослідження визначено основні риси органів виконавчої влади, а саме: 1) є частиною публічної адміністрації; 2) являє собою організацію, тобто колектив людей, об'єднаних для вчинення спільних дій; 3) створюється 3 волі держави та реалізує їі; 4) має політичні та державні посади; 5) його діяльність спрямована на вчинення державно-виконавчих дій, є підзаконною; 6) здійснює діяльність в межах компетенції, тобто на підставах, у порядку i y спосіб, передбачені законодавством; 7) має атрибути юридичної особи (відокремлене майно, рахунок, печатку, штамп тощо). Висвітлено підходи до класифікації органів виконавчої влади за різними критеріями. Розкрито систему органів виконавчої влади, яка включає три організаційно-правові структурні ланки, а саме:

1) вища - Кабінет Міністрів України; 2) центральна - міністерства, державні служби, державні агентства, державні інспекції, комісії [12] та центральні органи виконавчої влади зі спеціальним статусом; 3) адміністративно-територіальна - територіальні органи виконавчої влади та місцеві державні адміністрації.

\section{Список використаних джерел:}

1. Авер'янов В. Адміністративне право України. Академічний курс: підручник : у 2 т. Т. 1: Загальна частина. Київ, 2004. 584 с.

2. Стеценко С.Г. Виконавча влада та роль Конституції України в організації її діяльності. Юридична наука і практика. 2011. № 2. С. 67-72.

3. Колпаков В., Кузьменко О. Адміністративне право України : підручник. Київ, 2003. 544 с

4. Адміністративне право України : підручник / за заг. ред. Ю.П. Битяка, В.М. Гаращука, B.В. Зуй; 2-ге вид., перероб та доп. Харків: Право, 2013. 656 c.

5. Державна виконавча влада в Україні: формування та функціонування : зб. наук. пр. / кол. авт.; Наук. кер. Н.Р. Нижник. Київ: Вид-во УАДУ, 2000. 224 c.

6. Про заходи щодо впровадження Концепції адміністративної реформи в Україні : Указ Президента України від 22.07.1998 р. № 810/98. Офіиійний вісник Украӥни. 1999. № 21. С. 32.

7. Тиндик Н. Правова природа виконавчої влади в Україні. Митна справа. 2011. № 1. Ч. 2. C. $106-111$.

8. Журавльов Д. В. Оновлена характеристика органів виконавчої влади України. Правовий часопис Донбасу. 2018. № 1 (62). С. 108-113.

9. Малиновський В. Я. Природа І зміст політичної служби в Україні. Вісник Національного університету «Юридична академія України імені Ярослава Мудрого». 2018. № 2 (37). С. 67-76.

10. Завальний М.В. Органи виконавчої влади як суб'єкт адміністративного права. URL: file://C:/Users/\%D0\%9E/DownloadsB8.pdf (дата звернення: 10.05.2021).

11. Поняття, функції і види діяльності виконавчої влади. URL: https://osvita.ua/vnz/reports/ law/9665/ (дата звернення: 10.05.2021).

12. Про центральні органи виконавчої влади : Закон України від 17 березня 2011 року № 3166-VI. Відомості Верховної Ради Украйни. 2011. № 38. Ст. 385.

13. Конституційно-правовий статус Кабінету Міністрів України та інших органів виконавчої влади. URL: https://arm.naiau.kiev.ua/books/ konst pu/rozdil/rozdil10.html (дата звернення: 18.05.2021).

14. Журавльов Д. В. Поняття і загальна характеристика центральних органів виконавчої влади України. Публічне право. 2013. № 3 (11). С. 62-67.

15. Про Кабінет Міністрів України : Закон України від 27.02.2014 № 794-VII. Відомості Верховної Ради України. 2014. № 13. Ст. 222.

16. Хамходера О.П. Адміністративно-правовий статус інспекції як центрального органу виконавчої влади : дис. ... кандидата юрид. наук: 12.00.07. Одеса, 2014. 269 с.

17. Панфілов О.Є., Хамходера О.П. Комісія як новий вид центральних органів виконавчої влади: осмислення нормативних змін. Юридичний науковий електронний журнал. 2020. № 7. C. 282-286.

\footnotetext{
Natalia Borisocheva. Theoretical approaches to understanding the system of executive bodies

This scientific article, based on the analysis of theoretical approaches of administrative scientists on the theory of executive bodies and their system, investigates theoretical approaches to understanding the system of executive bodies, which allowed the author to propose his own definition of executive body and explore problematic issues of their activities.

It is determined that the main features of executive bodies are: 1) are part of public administration; 2) is an organization, ie a group of people united to perform joint actions; 3 ) is created at the will of the state and implements it; 4) holds political and state positions; 5) its activity is aimed at committing stateexecutive actions, is by-law; 6) carry out activities within the competence, ie on the grounds, in the manner and in the manner prescribed by law; 7) has the attributes of a legal entity (separate property, account, seal, stamp, etc.).

Thus, the executive branch is a part of the state apparatus that has its own structure and staff and within the established competence carries out on the basis of laws and their implementation, on its own behalf and on
} behalf of the people of Ukraine bylawes in the areas spheres and sectors of public relations. 
The system of executive bodies is a set in which all components (individual bodies and their structural units) are interconnected and at the same time constitute independent subsystems with their own features of structure, functions, competencies. The construction of this system is based on the principles of unity and integrity of the state territory, a combination of the principles of centralization and decentralization, balanced socio-economic development of regions depending on the administrative-territorial structure of the country.

It is determined that the state commissions are the central collegial body of executive power, the activity of which is directed and coordinated by the Cabinet of Ministers of Ukraine through a specially appointed Minister, the procedure of appointing its members and head is terminated by a special law public policy.

Key words: aviation, aviation branch, aircraft construction, civil aviation, commercial aviation, air transportation, air potential. 